\title{
An Increase in the Omega-6/Omega-3 Fatty Acid Ratio Increases the Risk for Obesity
}

\author{
Artemis P. Simopoulos \\ The Center for Genetics, Nutrition and Health, 4330 Klingle Street NW, Washington, DC 20016, USA; \\ cgnh@bellatlantic.net; Tel.: +1-202-462-5062; Fax: +1-202-462-5241
}

Received: 15 January 2016; Accepted: 15 February 2016; Published: 2 March 2016

\begin{abstract}
In the past three decades, total fat and saturated fat intake as a percentage of total calories has continuously decreased in Western diets, while the intake of omega-6 fatty acid increased and the omega- 3 fatty acid decreased, resulting in a large increase in the omega-6/omega-3 ratio from 1:1 during evolution to 20:1 today or even higher. This change in the composition of fatty acids parallels a significant increase in the prevalence of overweight and obesity. Experimental studies have suggested that omega- 6 and omega- 3 fatty acids elicit divergent effects on body fat gain through mechanisms of adipogenesis, browning of adipose tissue, lipid homeostasis, brain-gut-adipose tissue axis, and most importantly systemic inflammation. Prospective studies clearly show an increase in the risk of obesity as the level of omega- 6 fatty acids and the omega-6/omega- 3 ratio increase in red blood cell (RBC) membrane phospholipids, whereas high omega-3 RBC membrane phospholipids decrease the risk of obesity. Recent studies in humans show that in addition to absolute amounts of omega- 6 and omega-3 fatty acid intake, the omega-6/omega-3 ratio plays an important role in increasing the development of obesity via both AA eicosanoid metabolites and hyperactivity of the cannabinoid system, which can be reversed with increased intake of eicosapentaenoic acid (EPA) and docosahexaenoic acid (DHA). A balanced omega-6/omega-3 ratio is important for health and in the prevention and management of obesity.
\end{abstract}

Keywords: obesity; omega- 6 and omega- 3 essential fatty acids; omega- 6 and omega- 3 fatty acid ratio; eicosanoids; browning of adipose tissue; endocannabinoids; FTO (Fat Mass and Obesity-Associated) Gene

\section{Introduction}

Obesity is a complex condition involving the dysregulation of several organ systems and molecular pathways, including adipose tissue, liver, pancreas, gastrointestinal tract, the microbiome, the central nervous system (CNS), and genetics. The role of the CNS in obesity is receiving more attention as obesity rates rise and treatments continue to fail. While the role of the hypothalamus in the regulation of appetite and food intake has long been recognized, the roles of the CNS reward systems are beginning to be examined as the role of environmental influences on energy balance are explored. Furthermore, omega- 3 fatty acids hold great promise in the prevention and management of obesity.

Omega- 6 and omega- 3 polyunsaturated fatty acids (PUFAs) are essential fatty acids that must be derived from the diet, cannot be made by humans, and other mammals because of the lack of endogenous enzymes for omega-3 desaturation [1,2]. Due to agribusiness and modern agriculture western diets contain excessive levels of omega-6 PUFAs but very low levels of omega-3 PUFAs, leading to an unhealthy omega-6/omega-3 ratio of 20:1, instead of 1:1 that was during evolution in humans (Figure 1) [1,3]. 


\section{Hunter-gatherer Agricultural Industrial}

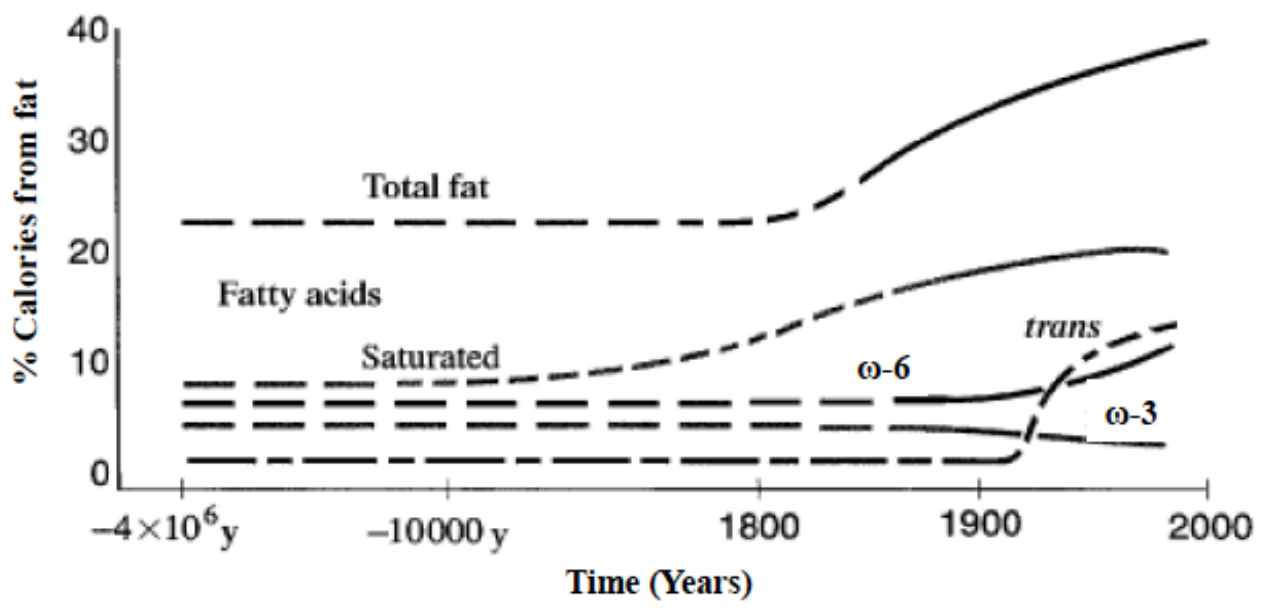

Figure 1. Hypothetical scheme of fat, fatty acid $(\omega 6, \omega 3$, trans, and total) intake (as percent of calories from fat). Data were extrapolated from cross-sectional analyses of contemporary hunter-gatherer populations and from longitudinal observations and their putative changes during the preceding 100 years (Modified from [3]).

Eicosanoid products derived from omega-6 PUFAs (such as prostaglandin (PG) E2 and leukotriene (LT) B4 synthesized from arachidonic acid (AA)) are more potent mediators of thrombosis and inflammation than similar products derived from omega-3 PUFAs (PGE3 and LTB5 synthesized from eicosapentaenoic acid (EPA)) (Figure 2) (Table 1) [1-3].

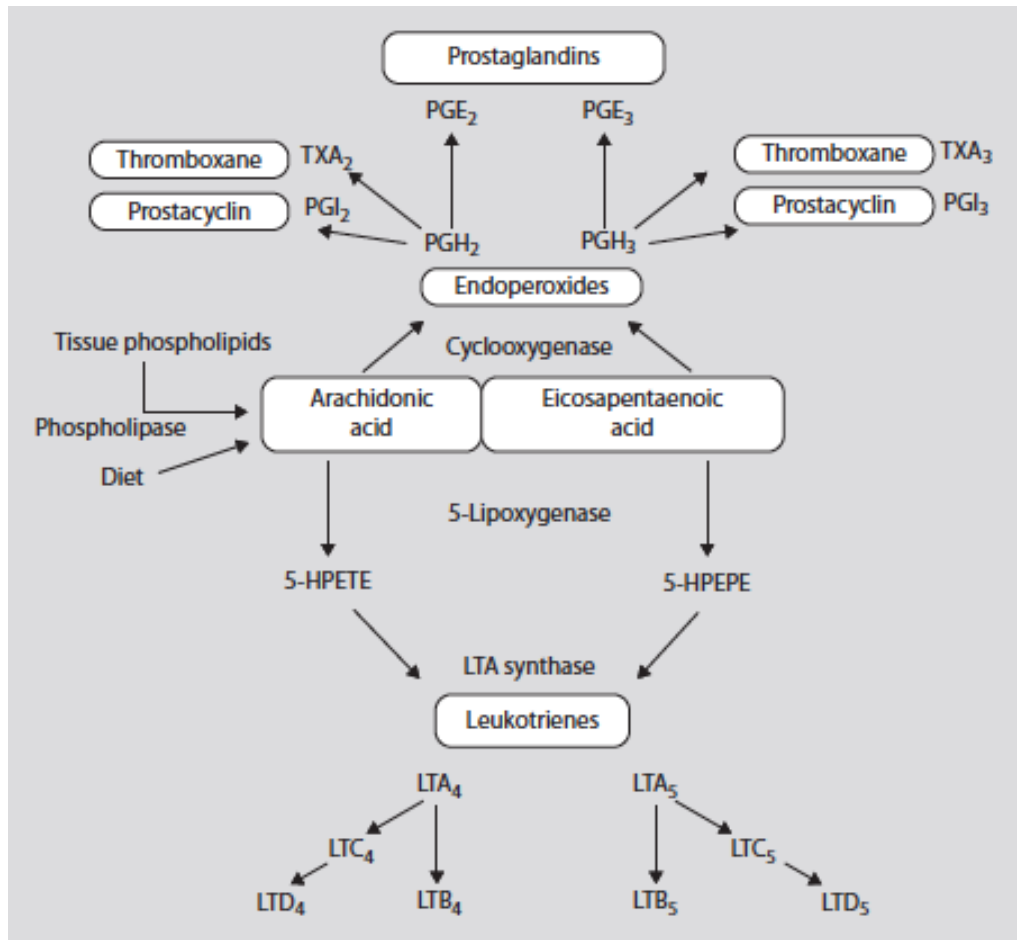

Figure 2. Oxidative metabolism of arachidonic acid (AA) and eicosapentaenoic acid by the cy-clooxygenase and 5-lipoxygenase pathways. 5-HPETE denotes the 5 hydroperoxyeicosatetranoic acid and 5-HPEPE denotes the 5-hydroxyeicosapentaenoic acid [3]. 
Table 1. Effects of Ingestion of eicosapentaenoic acid (EPA) and docosahexaenoic acid (DHA) from Fish or Fish Oil. Modified from [3].

\begin{tabular}{ll}
\hline- & Decreased production of prostaglandin E2 (PGE2) metabolites \\
\hline- & A decrease in thromboxane A2, a potent platelet aggregator and vasoconstrictor \\
\hline- & $\begin{array}{l}\text { A decrease in leukotriene B4 formation, an inducer of inflammation, and a powerful inducer of leukocyte } \\
\text { chemotaxis and adherence }\end{array}$ \\
\hline- & An increase in thromboxane A3, a weak platelet aggregator and weak vasoconstrictor \\
\hline- & An increase in prostacyclin PGI3 \\
\hline- & Both PGI2 and PGI3 are active vasodilators and inhibitors of platelet aggregation \\
\hline- & An increase in leukotriene B5, a weak inducer of inflammation and a weak chemotactic agent \\
\hline
\end{tabular}

Thus, an unbalanced omega-6/omega-3 ratio in favor of omega-6 PUFAs is highly prothrombotic and proinflammatory, which contributes to the prevalence of atherosclerosis, obesity, and diabetes [1-6]. In fact, regular consumption of diets rich in omega-3 PUFAs have been associated with low incidence of these diseases, particularly in Icelandic populations, Inuit indigenous people, and Native Americans in Alaska [7-9]. However, using fish oil as the primary source of omega-3 PUFAs to treat type 2 diabetes has not always met with success $[6,10,11]$. Although nutritional studies suggest that high omega-6/omega-3 ratios have contributed significantly to the "obesity epidemic" [12,13], clinical trials using omega-3 PUFAs as weight-reducing agents have produced conflicting findings of both positive [14-16] and negative effects [17-19] due to many factors (Table 2).

Table 2. Factors that affect outcomes in Obesity studies leading to conflicting results in clinical intervention trials (Modified from Reference [19]).

- Determination of the composition of the background diet in terms of omega- 6 and omega- 3 fatty acids and inflammatory markers i.e., US, UK and Northern European countries have the highest amount of LA + AA in their diets, which competes with omega-3 PUFAs; they also have the lowest amount of vegetable and fruit intake, which are needed for optimal absorption of omega-3 PUFA from supplements

- Background inflammation

- Some studies are using fish and others omega-3 supplements; studies show that a continuous daily intake of omega-3 supplements leads to higher concentrations in the blood than eating fish two times/week

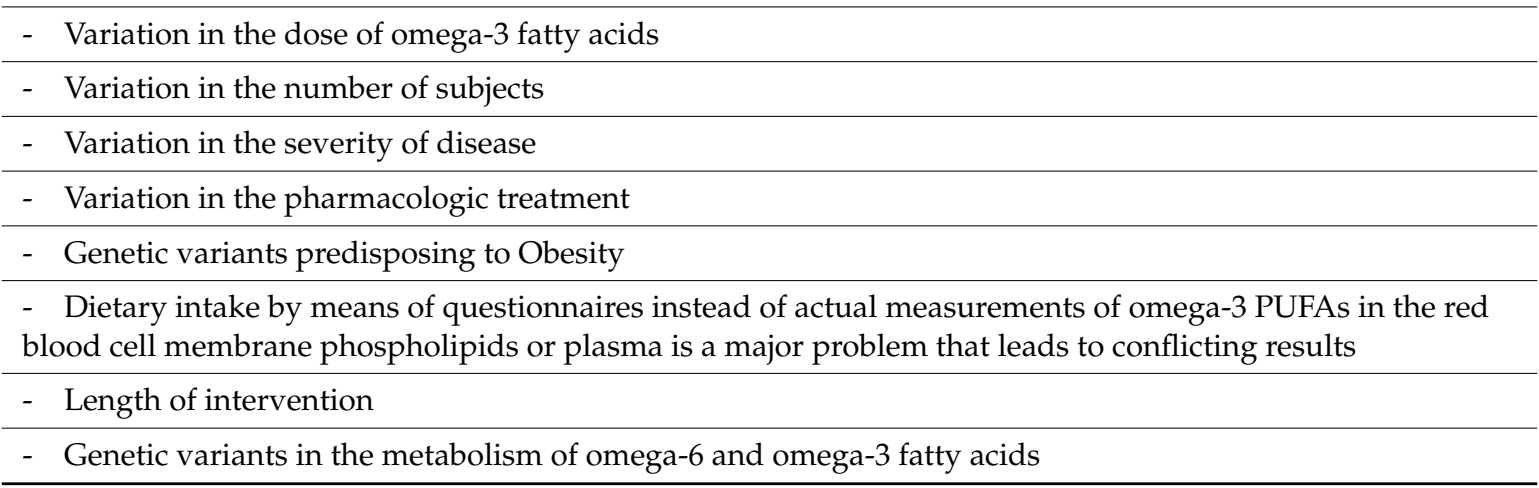

This paper focuses, on the differential aspects of omega- 6 and omega- 3 fatty acids and their ratio, in energy balance and in the prevention and management of obesity.

\section{The Importance of the Omega-6/Omega-3 Fatty Acid Ratio: Metabolic, Physiological and Evolutionary Aspects}

There are two classes of essential fatty acids (EFA), omega- 6 and omega-3. The distinction between omega- 6 and omega- 3 fatty acids is based on the location of the first double bond, counting from the methyl end of the fatty acid molecule. Omega- 6 fatty acids are represented by linoleic acid (LA) 
(18:2w-6) and omega-3 fatty acids by alpha-linolenic acid (ALA) (18:3w-3). LA is plentiful in nature and is found in the seeds of most plants except for coconut, cocoa, and palm. ALA, on the other hand, is found in the chloroplasts of green leafy vegetables, and in the seeds of flax, rape, chia, perilla and walnuts. Both essential fatty acids are metabolized to longer-chain fatty acids of 20 and 22 carbon atoms. LA is metabolized to arachidonic acid (AA) (20:4w6) while ALA is metabolized to eicosapentaenoic acid (EPA) (20:5w3) and docosahexaenoic acid (DHA) (22:6w3). This is achieved by increasing the chain length and the degree of unsaturation by adding extra double bonds to the carboxyl end of the fatty acid molecule [20] (Figure 3). AA is found predominantly in the phospholipids of grain-fed animals, dairy and eggs. EPA and DHA are found in the oils of fish, particularly fatty fish.

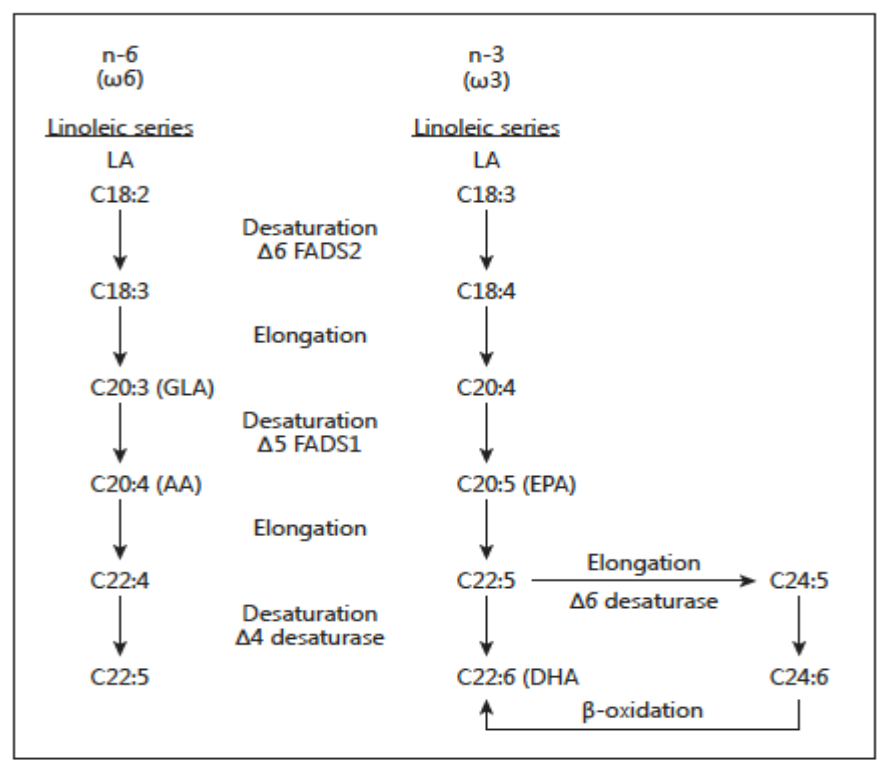

Figure 3. Desaturation and elongation of $\omega-3$ and $\omega-6$ fatty acids by the enzymes fatty acid de-saturases FADS2 (D6) and FADS1 (D5).

In mammals, including humans, the cerebral cortex, retina, testis and sperm are particularly rich in DHA. DHA is one of the most abundant components of the brain's structural lipids. DHA, like EPA, can be derived only from direct ingestion or by synthesis from dietary EPA or ALA: humans and other mammals, except for certain carnivores such as lions, can convert LA to AA and ALA to EPA and DHA, although the process is slow [21,22]. There is competition between omega- 6 and omega-3 fatty acids for the desaturation enzymes. Both fatty acid desaturase 1 (FADS1) and fatty acid desaturase 2 (FADS2) prefer ALA to LA $[21,23,24]$. However a high LA intake, such as that characterizing Western diets, interferes with the desaturation and elongation of ALA [22-25]. Similarly, trans fatty acids interfere with the desaturation and elongation of both LA and ALA.

There are important genetic variables in fatty acid biosynthesis involving FADS1 and FADS2, which encode rate-limiting enzymes for fatty acid metabolism (Figure 3). Ameur et al. [26] performed genome-wide genotyping ( $n=5652$ individuals) of the FADS region in five European population cohorts and analyzed available genomic data from human populations, archaic hominins, and more distant primates. Their results show that present-day humans have two common FADS haplotypes $A$ and $D$ that differ dramatically in their ability to generate long-chain polyunsaturated fatty acids (LC-PUFAs). The most common haplotype, denoted haplotype D, was associated with high blood lipid levels $\left(p=1 \times 10^{-65}\right)$, whereas the less common haplotype (haplotype A) was associated with low blood lipid levels $\left(p=1 \times 10^{-52}\right)$. The haplotype $\mathrm{D}$ associated with the enhanced ability to produce AA and EPA from their precursors LA and ALA respectively is specific to humans and has appeared after the split of the common ancestor of humans and Neanderthals. This haplotype shows evidence of a positive selection in African populations in which it is presently almost fixed and it is less frequent 
outside of Africa. Haplotype D provides a more efficient synthesis of LC-PUFAs and in today's high LA omega-6 dietary intake from vegetable oils, it leads to increased synthesis of AA from LA. As a result Haplotype D represents a risk factor for coronary heart disease (CHD), cancer, obesity, diabetes and the metabolic syndrome, adding further to health disparities in populations of African origin living in the West, in addition to lower socioeconomic status [27,28]. Furthermore, FADS2 is the limiting enzyme and there is some evidence that it decreases with age [21]. Premature infants [29], hypertensive individuals [30], and some diabetics [31] are limited in their ability to make EPA and DHA from ALA. These findings are important and need to be considered when making dietary recommendations. Genetic variants in FADS cluster are determinants of long-chain PUFA levels in circulation, cells and tissues. These genetic variants have been studied in terms of ancestry, and the evidence is robust relative to ethnicity. Thus, $80 \%$ of African Americans and about $45 \%$ of European Americans carry two copies of the alleles associated with increased levels of AA. It is quite probable that gene PUFA interactions induced by the modern Western diet are differentially driving the risk of diseases of inflammation (obesity, diabetes, atherosclerosis and cancer) in diverse populations.

As mentioned earlier, mammalian cells cannot convert omega- 6 to omega- 3 fatty acids because they lack the converting enzyme, omega-3 desaturase. Omega- 6 and omega-3 fatty acids are not interconvertible, are metabolically and functionally distinct, and often have important opposing physiological effects, therefore their balance in the diet is important. When humans ingest fish or fish oil, the EPA and DHA from the diet partially replace the omega- 6 fatty acids, especially AA, in the membranes of probably all cells, but especially in the membranes of platelets, erythrocytes, neutrophils, monocytes, and liver cells (reviewed in [3,32]). AA and EPA are the parent compounds for eicosanoid production. Because of the increased amounts of omega-6 in the Western diet, the eicosanoid metabolic products from AA, specifically prostaglandins, thromboxanes, leukotrienes, hydroxy fatty acids, and lipoxins, are formed in larger quantities than those derived from omega-3 fatty acids, specifically EPA [3]. The eicosanoids from AA are biologically active in very small quantities and, if they are formed in large amounts, they contribute to the formation of thrombus and atheromas; to allergic and inflammatory disorders, particularly in susceptible people; and to proliferation of cells [33]. Thus, a diet rich in omega- 6 fatty acids shifts the physiological state to one that is proinflammatory, prothrombotic, and proaggregatory, with increases in blood viscosity, vasospasm, vasoconstriction and cell proliferation.

A balance existed between omega- 6 and omega-3 fatty acids during the long evolutionary history of the genus Homo [34]. During evolution, omega-3 fatty acids were found in all foods consumed: particularly meat, fish, wild plants, nuts and berries [34-50]. Recent studies by Cordain et al. [51] on the composition of the meat of wild animals confirm the original observations of Crawford and Sinclair et al. [36,52]. However, rapid dietary changes over short periods of time as have occurred over the past 100-150 years is a totally new phenomenon in human evolution (Figure 1). A balance between the omega- 6 and omega- 3 fatty acids is a physiological state that is less inflammatory in terms of gene expression [53], prostaglandin and leukotriene metabolism, and interleukin-1 (IL-1) production [3].

Modern agriculture, by changing animal feeds as a result of its emphasis on production, has decreased the omega-3 fatty acid content in many foods: animal meats, eggs, and even fish [39-42]. Foods from edible wild plants contain a good balance of omega- 6 and omega- 3 fatty acids. Purslane, a wild plant, in comparison to spinach, red leaf lettuce, buttercrunch lettuce and mustard greens, has eight times more ALA than the cultivated plants [46]. Modern aquaculture produces fish that contain less omega-3 fatty acids than do fish grown naturally in the ocean, rivers and lakes [41]. The fatty acid composition of egg yolk from free-ranging chicken has an omega-6:omega-3 ratio of 1.3 whereas the United States Department of Agriculture (USDA) egg has a ratio of 19.9 [42]. By enriching the chicken feed with fishmeal or flaxseed, the ratio of omega-6:omega-3 decreased to 6.6 and 1.6 respectively.

Although diets differ in the various geographic areas [54], a number of investigators including Crawford [36], Cordain [51], Eaton [55] and Kupiers [56] have shown that during the Paleolithic period, the diets of humans included equal amounts of omega- 6 and omega- 3 fatty acids from both plants (LA 
+ ALA) and from the fat of animals in the wild and fish (AA + EPA + DHA). Recent studies by Kuipers et al. [56] estimated macronutrient and fatty acid intakes from an East African Paleolithic diet in order to reconstruct multiple Paleolithic diets and thus estimate the ranges of nutrient intakes on which humans evolved. They found (range of medians in energy \%) intakes of moderate-to-high protein $(25 \%-29 \%)$, moderate-to-high fat $(30 \%-39 \%)$ and moderate carbohydrates $(39 \%-40 \%)$. Just as others have concluded previously, Kuipers et al. [56] stated, "compared with Western diets, Paleolithic diets contained consistently high protein and long-chain PUFA and lower LA". Guil-Guerrero J et al. [57] determined the fat composition of frozen mammoths (from 41,000 to 34,000 years BP), Bisons from early Holocene (8200-9300 years BP) and horses from middle Holocene (4600-4400 years BP), often consumed by Paleolithic/Neolithic hunters gatherers, and concluded, that "the animal fat contained suitable amounts of omega-3 and omega-6 fatty acids, possibly in quantities sufficient to meet today's dietary requirements for good health". The elucidation of sources of omega-3 fatty acids available for the humans who lived in the Paleolithic and Neolithic is highly relevant to ascertain the availability of nutrients at that time and to draw conclusions about healthy dietary habits for present-day humans. As in previous studies, the amount of ALA was higher than LA in the fat of the frozen specimens $[58,59]$ (Tables 3 and 4).

Table 3. Estimated Omega-3 and Omega-6 Fatty Acid intake in the Late Paleolithic Period (g/day) ${ }^{a, b, c}$.

\begin{tabular}{cc}
\hline Plants & \\
LA & 4.28 \\
ALA & 11.40 \\
\hline Animals & \\
LA & 4.56 \\
ALA & 1.21 \\
\hline Total & \\
LA & 8.84 \\
ALA & 12.60 \\
\hline Animal & \\
AA $(\omega 6)$ & 1.81 \\
EPA $(\omega 3)$ & 0.39 \\
DTA $(\omega 6)$ & 0.12 \\
DPA $(\omega 3)$ & 0.42 \\
DHA $(\omega 3)$ & 0.27 \\
\hline Ratios of $\omega 6 / \omega 3$ & \\
LA $/$ ALA & 0.70 \\
Total $\omega 6 / \omega 3$ & 1.79 \\
AA + DTA EPA + DPA + DHA & $0.79 \mathrm{~b}$
\end{tabular}

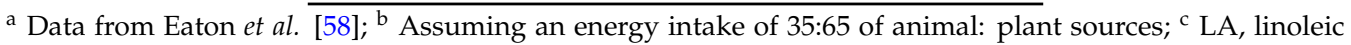
acid; ALA, linolenic acid; AA, arachidonic acid; EPA, eicosapentaenoic acid; DTA, docosatetranoic acid; DPA, docosapentaenoic acid; DHA, docosahexaenoic acid.

Table 4. Omega-6/Omega-3 Ratios in Different Populations.

\begin{tabular}{cc}
\hline Population & $\omega-6 / \omega-3$ \\
\hline Paleolithic & 0.79 \\
Greece prior to 1960 & $1.00-2.00$ \\
Current Japan & 4.00 \\
Current India, rural & $5-6.1$ \\
Current UK and northern Europe & 15.00 \\
Current US & 16.74 \\
Current India, urban & $38-50$ \\
\hline
\end{tabular}




\section{Effects of Omega-6 and Omega-3 Fatty Acids and their Ratio on Obesity}

Experimental studies have suggested that omega- 3 and omega- 6 fatty acids may elicit divergent effects on body fat gain through mechanisms of adipogenesis [60], lipid homeostasis [61,62], brain-gut-adipose tissue axis [63], and systemic inflammation [64]. Metabolites of AA (20:4w-6) play important roles in the terminal differentiation of pre-adipocyte to mature adipocyte [65]. This effect can be inhibited by omega-3 fatty acids at multiple steps [66-69]. Omega-6 fatty acids increase cellular triglyceride content by increasing membrane permeability [70], while omega-3 fatty acids reduce fat deposition in adipose tissues by suppressing lipogenic enzymes and increasing $\beta$-oxidation [71]. In addition, omega- 6 and omega- 3 fatty acids differentially modulate the brain-gut-adipose tissue axis [63] and the inflammatory properties of downstream eicosanoids, which ultimately affect pre-adipocyte differentiation and fat mass growth [72]. White adipocytes are storing energy in the form of triglycerides whereas brown adipocytes dissipate energy from triglycerides by producing heat (Table 5). In rodents and possibly in humans both types of fat cells participate in the total energy balance. By altering rates of adipocyte differentiation and proliferation, differences in fatty acid composition of dietary fats may also contribute to adipose tissue development, in particular with respect to the relative intake of omega- 6 and omega- 3 fatty acids. The omega-6/omega-3 ratio determines the availability of omega-6-AA within adipose tissue and thus the level of various prostaglandins derived from the cyclooxygenase-mediated pathways, which can be blocked by omega-3 fatty acids (Figure 2). Recent studies have shown that perinatal exposure of mice to a high omega- 6 fatty acid diet (similar to Western diet) results in a progressive accumulation of body fat across generations, which is consistent with the fact that in humans, overweight and obesity have steadily increased in the last decades, and emerge earlier in life [12,73]. Furthermore, AA metabolites prostaglandins E2 and F2 $\alpha$ have an inhibitory role in the browning process of white fat cells converted into energy-dissipating brown fat cells which are believed to play a role in controlling energy balance by lowering body weight [74-82] (Table 5).

High intake of omega- 6 fatty acids during the perinatal period is associated with increased adiposity in the offspring. In human studies the level of AA in adipose tissue is associated with the BMI and overweight status of children. High omega-6/omega-3 fatty acids in umbilical cord red blood cell (RBC) membrane phospholipids was associated with high subscapular skin-fold thickness at 3 years of age [5].

Animal and human studies have shown that EPA and DHA supplementation may be protective against obesity, and may reduce weight gain in already obese animals and humans [83]. Specifically, studies demonstrated a reduction in visceral (epididymal and/or retroperitoneal) fat in rats fed high lipid diets that incorporate omega-3 PUFAs [75,78,79,84-87], and the effect was dose-dependent [85]. The reduction in visceral fat was associated with a decrease in adipocyte size $[85,86]$ and number $[87]$. High fat diets rich in omega- 6 fatty acids have been shown to increase the risk of leptin resistance, diabetes, and obesity in humans and rodents $[76,88]$. AA impairs hypothalamic leptin signaling and energy homeostasis in mice [77]. The inhibitory role of AA has been suggested in both basal and insulin-stimulated leptin expression and production [88]. 
Table 5. Opposing Effects of Omega-6 and Omega-3 Fatty Acids in Obesity.

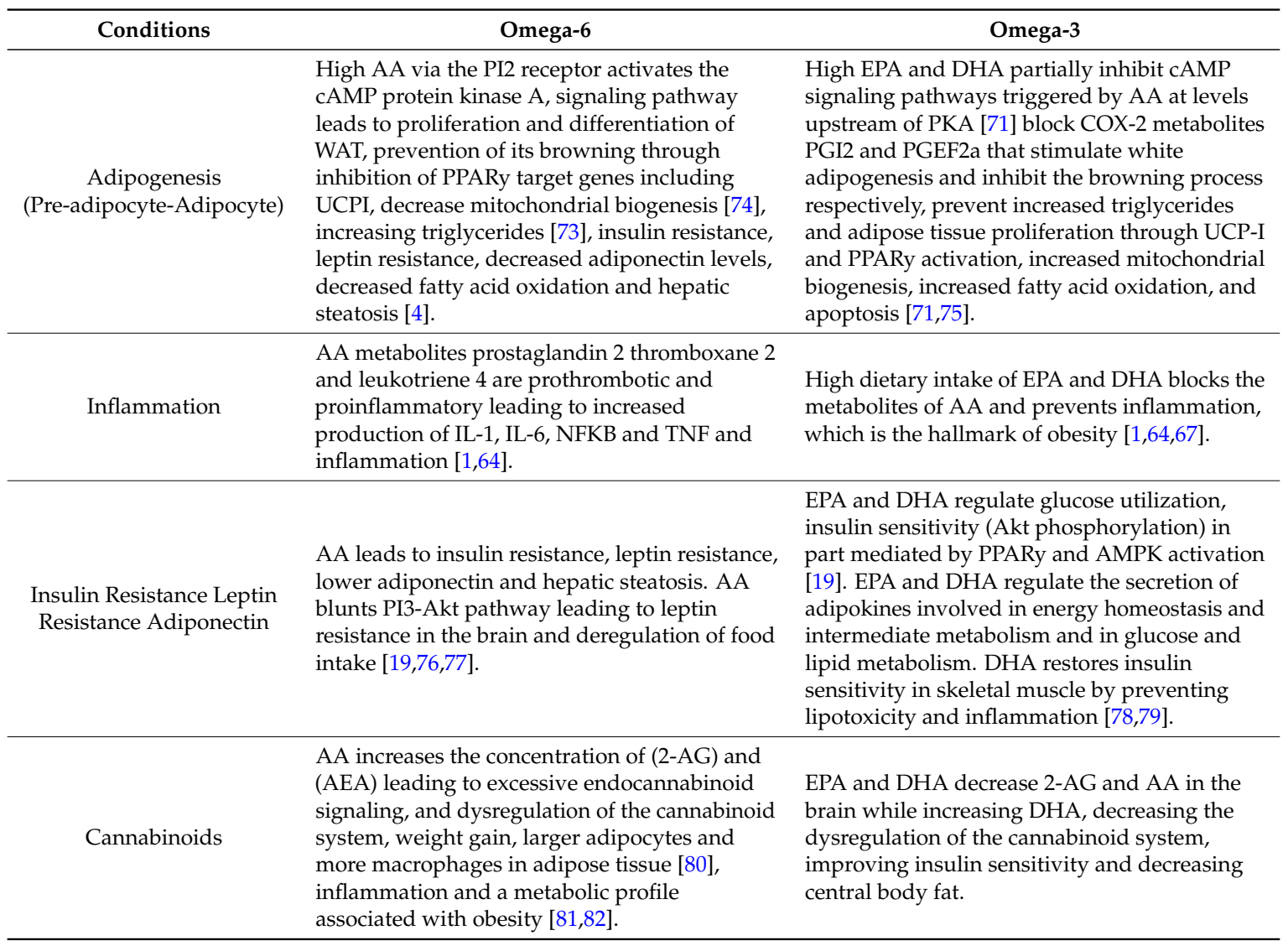

\subsection{The Fat-1 Transgenic Mouse Model}

Many of the problems involving dietary animal studies can be overcome by the fat- 1 transgenic mouse model that carries a Caenorhabditis elegans fat- 1 gene encoding an omega- 3 fatty acid desaturase. This enzyme can convert omega- 6 to omega- 3 fatty acids by adding a double bond at the omega-3 position [89]. Consequently, fat-1 not only increases the levels of omega- 3 fatty acids but also concomitantly decreases omega- 6 fatty acids as well as the omega-6/omega-3 ratio-a goal difficult to achieve through dietary means alone, yet important for health benefits. Although not fully equated to a dietary approach, the transgenic model produces the same types of omega-3 fatty acids as those obtained through diet [89].

Furthermore, the fat- 1 model offers numerous advantages in the studies of the health benefits of omega-3 fatty acids, because the transgenic model allows elucidation of the mechanisms of actions of omega-3 fatty acids without the confounding issues associated with dietary approaches, such as dose, composition, and duration of treatment applied in different studies [16,90,91] (Table 2). The use of fat- 1 mouse model avoids these concerns by feeding exactly the same diet to the transgenic and wild type (WT) mice. Because FAT- 1 is an enzyme, the production of omega-3 fatty acids in mice is limited by the amount of available substrate: omega- 6 fatty acids. The degree of increase in omega- 3 fatty acids (3- to 4-fold) required to improve metabolic parameters in fat- 1 transgenic mice has been shown to be achievable through dietary means in animals and humans [92]. Recently Li et al. [93] carried out a comprehensive study using the fat- 1 model to better define how alterations in the tissue levels of omega-6 and omega-3 fatty acids affect energy balance, lipid and glucose metabolism, chronic inflammation, and the underlying molecular events (or mechanisms). Their results show that when challenged with high-fat diets, fat-1 mice strongly resisted obesity, diabetes, hypercholesterolemia, and hepatic steatosis. Endogenous elevation of omega-3 PUFAs and reduction of omega-6 PUFAs did not alter the amount of food intake but led to increased energy expenditure in the fat- 1 mice. 
These metabolic phenotypes were accompanied by attenuation of the inflammatory state because tissue levels of prostaglandin E2, leukotriene B4, monocyte chemoattractant protein-1, and TNF- $\alpha$ were significantly decreased. The TNF- $\alpha$-induced NF- $\mathrm{B}$ signaling was almost completely abolished. Consistent with the reduction in chronic inflammation and a significant increase in peroxisome proliferator-activated receptor- $\gamma$ activity in the fat- 1 liver tissue, hepatic insulin signaling was sharply elevated. The activities of prolipogenic regulators, such as liver X receptor, stearoylCoA desaturase-1, and sterol regulatory element binding protein-1 were sharply decreased, whereas the activity of peroxisome proliferator-activated receptor- $\alpha$, a nuclear receptor that facilitates lipid $\beta$-oxidation, was markedly increased [93]. Thus, endogenous conversion of omega-6 to omega-3 PUFAs via fat-1 strongly protects against obesity, diabetes, inflammation, and dyslipidemia and may represent a novel therapeutic modality to treat these prevalent disorders.

\subsection{Human Studies}

Randomized controlled trials in humans examining the relationship between omega-3 supplementation and body composition have produced conflicting results due to many factors summarized in Table 2 [19,83]. This may be due to differences in study design, dosage, not taking into consideration the omega-6/omega-3 ratio of the background diet, timing, and duration of omega-3 PUFA administration, use of other supplements in addition to omega-3 PUFA, and demographics of the study population. Furthermore, in many studies the determination of omega-6/omega-3 fatty acids was based on food frequency questionnaires, which are not as accurate as direct measurements of fatty acids in RBC membrane phospholipids. Several studies have provided supporting evidence for a role of omega-3 PUFAs in body composition [94], weight reduction [95], less hunger and more fullness [96]. These findings support a potential role for omega-3 in appetite regulation in humans. Some intervention studies showed that omega-3 fatty acid supplementation reduced body weight and obesity in lean [14], overweight [95,97] and obese [98] individuals. Couet et al. [14] noted a 22\% increase in basal lipid oxidation with 6 grams of fish oil for 3 weeks. Omega-3 fatty acids are long term metabolic fuel partitioners with greater partitioning towards $\beta$-oxidation in men than in women.

Omega-6 and omega-3 red blood cell membrane phospholipid determinations represent biomarkers of dietary intake plus endogenous metabolism and represent the most accurate way to carry out preventive studies and clinical intervention studies to evaluate their role in weight gain and obesity [99]. Wang et al. [100] conducted a prospective analysis to examine the association of baseline red blood cell membrane phospholipids of omega- 3 fatty acids, omega- 6 fatty acids, omega-6/omega- 3 ratio and trans fatty acids with the longitudinal changes in body weight and the risk of becoming overweight or obese during a mean of 10.4 years follow up in the NIH Women's Health Initiative Study. The results of this prospective study showed that baseline red blood cell membrane phospholipids cis omega-3 fatty acids is inversely associated, and cis omega-6 fatty acids are positively associated, with longitudinal weight gain in initially normal weight healthy women. This is the first study to prospectively examine omega-3 and omega- 6 fatty acids in red blood cell membrane phospholipids in relation to weight gain and the risk of becoming overweight or obese. After multivariable adjustment, significant positive associations with weight gain were found only for dihomo- $\gamma$-linolenic acid (DGLA), LA, and Gamma-linolenic acid (GLA) among omega-6 fatty acids and trans 18:1 among trans fatty acids; while inverse associations were found with EPA among omega-3 fatty acids. The authors state that, "the variations by individual fatty acids may be due to unknown and uncontrolled factors involved in the conversion and metabolism of each fatty acid, and should be interpreted cautiously given the multiple comparisons. This study included only women who had normal BMI at baseline to minimize potential confounding and address the risk of becoming overweight or obese". To further evaluate the impact of baseline BMI on the results, Wang et al. [100] stratified analyses by baseline BMI levels $\left(18.5-\leqslant 23,23-\leqslant 25 \mathrm{~kg} / \mathrm{m}^{2}\right)$ and also included women who were already overweight or obese at baseline (baseline BMI $\geqslant 25 \mathrm{~kg} / \mathrm{m}^{2}$ ) in sensitivity analyses. Similar patterns of associations were found in these additional analyses. In conclusion, this prospective study provided strong suggestive 
evidence that omega-3 fatty acids in RBC membrane phospholipids are inversely associated, while cis omega-6 fatty acids, omega-6/omega-3 ratio, and trans fatty acids are positively associated, with longitudinal weight gain.

\section{Genetics: The Fat Mass and Obesity-Associated Gene}

Genome-Wide Association Studies (GWAS) have identified more than 90 loci that contain genetic variants associated with obesity. Many of these variants are in intronic regions. The strongest genetic association with risk to polygenic obesity are single-nucleotide variants (SNV) in intron 1 and 2 of the FTO (fat mass and obesity associated) gene. There are 89 SNVs in FTO intron 1 and 2. Deciphering how these variants regulate gene expression has been difficult. Recently Claussnitzer et al. [101] reported a strategy and defined the causal SNV and the mechanisms of function in preadipocytes. The authors provide evidence for the rs $1421085 \mathrm{~T}$ to C SNV to result in a cellular phenotype consistent with obesity in primary human adipocytes, including decreased mitochondrial energy generation and increased triglyceride accumulation.

Their study provided evidence that the risk allele rs $1411085 \mathrm{~T}$ to C SNV resulted in increased expression of IRX3 and IRX5 genes in pre-adipocytes, which shifted the development of these cells toward the "white program" and increased lipid storage, whereas knockdown of IRX3 and IRX5 genes restored thermogenesis in adipocytes from persons at high risk for obesity. Thus, the risk allele functioned similarly to AA metabolites, PGI2 and PGF2a, increasing proliferation of white adipose tissue and decreasing its browning respectively, whereas the knockdown of IRX3 and IRX5 genes functioned similarly to omega-3 fatty acid metabolites increasing the browning of the adipose tissue, mitochondrial biogenesis and thermogenesis. The arachidonic acid metabolites PGI2 and PGF2a lead to increases in white adipose tissue and decreases its browning respectively. Human studies have shown a direct relationship between plasma arachidonic acid levels and infant body weight, as well as between AA levels in adipose tissue lipids and BMI in children in Cyprus and Crete [102,103]. AA directly inhibits UCPI gene expression. Considering the high omega-6/omega-3 fatty acid ratio of Western diets and the role of AA in adipose cell differentiation, proliferation, and decreasing browning of white adipose tissue, further research should include studies on the effects of omega- 3 fatty acids in blocking the effects of the risk allele (rs 1421085), which appears to be responsible for the association between the first intron of FTO gene and obesity in humans.

\section{Omega-6/Omega-3 Fatty Acid Ratio: Endocannabinoid System}

A diet high in the omega-6/omega-3 ratio causes an increase in the endocannabinoid signaling and related mediators, which lead to an increased inflammatory state, energy homeostasis, and mood. In animal experiments a high omega- 6 acid intake leads to decreased insulin sensitivity in muscle and promotes fat accumulation in adipose tissue. Nutritional approaches with dietary omega-3 fatty acids reverse the dysregulation of this system, improve insulin sensitivity and control body fat.

Endocannabinoids are lipids, derived from the omega-6 AA. Their concentrations are regulated by (1) dietary intake of omega- 6 and omega-3 fatty acids; and (2) by the activity of biosynthetic and catabolic enzymes involved in the endocannabinoid pathway, which is an important player in regulation of appetite and metabolism [81,104]. The endocannabinoid system is involved in regulation of energy balance and sustained hyperactivity of the endocannabinoid system contributes to obesity [81,82]. AA is the precursor of 2-arachidonoylglycerol (2-AG) and anandamide (AEA). Increasing the precursor pool of AA causes excessive endocannabinoid signaling leading to weight gain and a metabolic profile associated with obesity. Endocannabinoids activate endogenous cannabinoid CB1 and CB2 receptors in the brain, liver, adipose tissue, and the gastrointestinal tract [105]. Activation of CB1 receptors in the hypothalamus leads to increased appetite and food intake [82]. In mouse experiments endocannabinoids selectively enhance sweet taste, which in the current highly palatable food supply stimulate food intake [106]. The endocannabinoid system functions in concert with other systems regulating food intake and energy balance, and is regulated by leptin, insulin, ghrelin, 
cholecystokinin, and other signals. Targeting the endocannabinoid system has been a strategy for weight loss. Randomized controlled clinical trials in overweight or obese humans showed that CB1 receptor antagonists such as rimonabant led to significant weight loss after one year of treatment [107]. However the drug was withdrawn from the market due to severe side effects that led to increased risk of anxiety, depression, and suicide [108].

Alvheim et al. [80] carried out an experiment in mice at six weeks of age, in which increasing the linoleic acid in the diet led to increases in AA in red blood cell membrane phospholipids, elevated 2-AG and AEA in liver, elevated plasma-leptin and resulted in larger adipocytes and more macrophage infiltration in adipose tissue. It was also noted that a higher linoleic acid increased feed efficacy and caused greater weight gain than isocaloric diets containing less LA. Increasing the dietary LA from $1 \%$ to $8 \%$ of energy increased liver endocannabinoid levels, which increased the risk of developing obesity, even in a low fat diet. Mice chronically deficient in omega-3 PUFA have significantly lower concentrations of DHA in brain phospholipids, and higher 2-AG (derived from AA) compared to mice with sufficient omega-3 PUFA in their diet [82]. Furthermore, omega-3 PUFA supplementation of mice with $10 \%$ weight DHA-rich fish oil for 4 weeks led to higher brain DHA levels compared to mice on a low omega-3 PUFA diet, and led to a significant decrease in brain 2-AG and brain AA. This nutritional approach with dietary omega-3 PUFA, reversed the dysregulation of the cannabinoid system, improved insulin sensitivity and decreased central body fat.

\section{Conclusions and Recommendations}

- Human beings evolved on a diet that was balanced in the omega-6 and omega-3 essential fatty acids.

- A high omega-6 fatty acid intake and a high omega-6/omega-3 ratio are associated with weight gain in both animal and human studies, whereas a high omega-3 fatty acid intake decreases the risk for weight gain. Lowering the LA/ALA ratio in animals prevents overweight and obesity.

- Omega-6/omega-3 fatty acids compete for their biosynthetic enzymes and because they have distinct physiological and metabolic properties, their balanced omega-6/omega-3 ratio is a critical factor for health throughout the life cycle.

- Adipose tissue is the main peripheral target organ handling fatty acids, and AA is required for adipocyte differentiation (adipogenesis). The increased LA and AA content of foods has been accompanied by a significant increase in the AA/EPA + DHA ratio within adipose tissue, leading to increased production in AA metabolites, PGI2 which stimulates white adipogenesis and PGF2 $\alpha$ which inhibits the browning process, whereas increased consumption of EPA and DHA leads to adipose tissue homeostasis through adipose tissue loss and increased mitochondrial biogenesis.

- High omega-6 fatty acid intake leads to hyperactivity of endocannabinoid system, whereas omega-3 fatty acids lead to normal homeostasis (decrease hyperactivity).

- High omega-6 fatty acids increase leptin resistance and insulin resistance, whereas omega-3 fatty acids lead to homeostasis and weight loss.

- Because a high omega-6/omega-3 ratio is associated with overweight/obesity, whereas a balanced ratio decreases obesity and weight gain, it is essential that every effort is made to decrease the omega- 6 fatty acids in the diet, while increasing the omega- 3 fatty acid intake. This can be accomplished by (1) changing dietary vegetable oils high in omega-6 fatty acids (corn oil, sunflower, safflower, cottonseed, and soybean oils) to oils high in omega-3s (flax, perilla, chia, rapeseed), and high in monounsaturated oils such as olive oil, macadamia nut oil, hazelnut oil, or the new high monounsaturated sunflower oil; and (2) increasing fish intake to 2-3 times per week, while decreasing meat intake. 
- In clinical investigations and intervention trials it is essential that the background diet is precisely defined in terms of the omega- 6 and omega- 3 fatty acid content. Because the final concentrations of omega- 6 and omega- 3 fatty acids are determined by both dietary intake and endogenous metabolism, it is essential that in all clinical investigations and intervention trials the omega- 6 and omega-3 fatty acids are precisely determined in the red blood cell membrane phospholipids. In severe obesity drugs and bariatric surgery have been part of treatment.

- The risk allele rs $1421085 \mathrm{~T}$ to C SNV in intron 1 and 2 in the FTO gene functioned similarly to AA metabolites, PGI2 and PGF2a increasing proliferation of white adipose tissue and decreasing its browning respectively, whereas the knockdown of IRX3 and IRX5 genes functioned similarly to omega-3 fatty acid metabolites increasing the browning of white adipose tissue, mitochondrial biogenesis, and thermogenesis. Therefore, further research should include studies on the effects of omega-3 fatty acids in blocking the effects of the risk allele (rs 1421085), which appears to be responsible for the association between the first intron of FTO gene and obesity in humans.

- In the future studies on genetic variants from GWAS will provide opportunities to precisely treat and prevent obesity by both nutritional and pharmaceutical interventions.

Obesity is a preventable disease that can be treated through proper diet and exercise. A balanced omega-6/omega-3 ratio 1-2/1 is one of the most important dietary factors in the prevention of obesity, along with physical activity. A lower omega-6/omega-3 ratio should be considered in the management of obesity.

Acknowledgments: I have not received any source of funding for this article.

Conflicts of Interest: The author declares no conflict of interest.

\section{References}

1. Simopoulos, A.P. Evolutionary aspects of diet and essential fatty acids. In Fatty Acids and Lipids-New Findings; Hamazaki, T., Okuyama, H., Eds.; Karger: Basel, Switzerland, 2001; Volume 88, pp. $18-27$.

2. Kang, J.X. The importance of omega- 6 /omega-3 fatty acid ratio in cell function. The gene transfer of omega-3 fatty acid desaturase. In Omega-6/Omega-3 Essential Fatty Acid Ratio: The Scientific Evidence; Simopoulos, A.P., Cleland, L.G., Eds.; Karger: Basel, Switzerland, 2003; Volume 92, pp. 23-36.

3. Simopoulos, A.P. The importance of the omega-6/omega-3 Fatty Acid ratio in cardiovascular disease and other chronic diseases. Exp. Biol. Med. 2008, 233, 674-688. [CrossRef] [PubMed]

4. Simopoulos, A.P. Dietary Omega-3 Fatty Acid Deficiency and High Fructose Intake in the Development of Metabolic Syndrome, Brain Metabolic Abnormalities, and Non-Alcoholic Fatty Liver Disease. Nutrients 2013, 5, 2901-2923. [CrossRef] [PubMed]

5. Donahue, S.M.; Rifas-Shiman, S.L.; Gold, D.R.; Jouni, Z.E.; Gillman, M.W.; Oken, E. Prenatal fatty acid status and child adiposity at age 3 years: Results from a US pregnancy cohort. Am. J. Clin. Nutr. 2011, 93, 780-788. [CrossRef] [PubMed]

6. Kromhout, D.; de Goede, J. Update on cardiometabolic health effects of $\omega-3$ fatty acids. Curr. Opin. Lipidol. 2014, 25, 85-90. [CrossRef] [PubMed]

7. Kromann, N.; Green, A. Epidemiological studies in the Upernavik district, Greenland. Incidence of some chronic diseases 1950-1974. Acta Med. Scand. 1980, 208, 401-406. [CrossRef] [PubMed]

8. Adler, A.I.; Boyko, E.J.; Schraer, C.D.; Murphy, N.J. Lower prevalence of impaired glucose tolerance and diabetes associated with daily seal oil or salmon consumption among Alaska Natives. Diabetes Care 1994, 17, 1498-1501. [CrossRef] [PubMed]

9. Schraer, C.D.; Risica, P.M.; Ebbesson, S.O.; Go, O.T.; Howard, B.V.; Mayer, A.M. Low fasting insulin levels in Eskimos compared to American Indians: are Eskimos less insulin resistant? Int. J. Circumpolar Health 1999, 58, 272-280. [PubMed]

10. Nettleton, J.A.; Katz, R. n-3 long-chain polyunsaturated fatty acids in type 2 diabetes: A review. J. Am. Diet. Assoc. 2005, 105, 428-440. [CrossRef] [PubMed]

11. Mozaffarian, D.; Rimm, E.B. Fish intake, contaminants, and human health: Evaluating the risks and the benefits. JAMA 2006, 296, 1885-1899. [CrossRef] [PubMed] 
12. Birch, E.E.; Hoffman, D.R.; Castañeda, Y.S.; Fawcett, S.L.; Birch, D.G.; Uauy, R.D. A randomized controlled trial of long-chain polyunsaturated fatty acid supplementation of formula in term infants after weaning at 6 wk of age. Am. J. Clin. Nutr. 2002, 75, 570-580. [PubMed]

13. Guesnet, P.; Pugo-Gunsam, P.; Maurage, C.; Pinault, M.; Giraudeau, B.; Alessandri, J.M.; Durand, G.; Antoine, J.M.; Couet, C. Blood lipid concenttrations of docosahexaenoic and arachidonic acids at birth determine their relative postnatal changes in term infants fed breast milk or formula. Am. J. Clin. Nutr. 1999, 70, 292-298. [PubMed]

14. Couet, C.; Delarue, J.; Ritz, P.; Antoine, J.M.; Lamisse, F. Effect of dietary fish oil on body fat mass and basal fat oxidation in healthy adults. Int. J. Obes. Relat. Metab. Disord. 1997, 21, 637-643. [CrossRef] [PubMed]

15. Fontani, G.; Corradeschi, F.; Felici, A.; Alfatti, F.; Bugarini, R.; Fiaschi, A.I.; Cerretani, D.; Montorfano, G.; Rizzo, A.M.; Berra, B. Blood profiles, body fat and mood state in healthy subjects on different diets supplemented with omega-3 polyunsaturated fatty acids. Eur. J. Clin. Investig. 2005, 35, 499-507. [CrossRef] [PubMed]

16. Hill, A.M.; Buckley, J.D.; Murphy, K.J.; Howe, P.R. Combining fish-oil supplements with regular aerobic exercise improves body composition and cardiovascular disease risk factors. Am. J. Clin. Nutr. 2007, 85, 1267-1274. [PubMed]

17. Belury, M.A.; Mahon, A.; Banni, S. The conjugated linoleic acid (CLA) isomer, t10c12-CLA, is inversely associated with changes in body weight and serum leptin in subjects with type 2 diabetes mellitus. J. Nutr. 2003, 133, 257S-260S. [PubMed]

18. Chan, D.C.; Watts, G.F.; Nguyen, M.N.; Barrett, P.H. Factorial study of the effect of $n-3$ fatty acid supplementation and atorvastatin on the kinetics of HDL apolipoproteins A-I and A-II in men with abdominal obesity. Am. J. Clin. Nutr. 2006, 84, 37-43. [PubMed]

19. Simopoulos, A.P. The Impact of the Bellagio Report on Healthy Agriculture, Healthy Nutrition, Healthy People: Scientific and Policy Aspects and the International Network of Centers for Genetics, Nutrition and Fitness for Health. J. Nutrigenet. Nutrigenom. 2015, 7, 189-209. [CrossRef] [PubMed]

20. Simopoulos, A.P. $\omega-3$ fatty acids in health and disease and in growth and development. Am. J. Clin. Nutr. 1991, 54, 438-463. [PubMed]

21. De Gomez Dumm, I.N.T.; Brenner, R.R. Oxidative desaturation of alphalinolenic, linoleic, and stearic acids by human liver microsomes. Lipids 1975, 10, 315-317. [CrossRef] [PubMed]

22. Emken, E.A.; Adlof, R.O.; Rakoff, H.; Rohwedder, W.K. Metabolism of deuterium-labeled linolenic, linoleic, oleic, stearic and palmitic acid in human subjects. In Synthesis and Application of Isotopically Labeled Compounds 1988; Baillie, T.A., Jones, J.R., Eds.; Elsevier Science Publishers: Amsterdam, The Netherlands, 1989; pp. 713-716.

23. Hague, T.A.; Christoffersen, B.O. Effect of dietary fats on arachidonic acid and eicosapentaenoic acid biosynthesis and conversion to C22 fatty acids in isolated liver cells. Biochim. Biophys. Acta 1984, 796, 205-217.

24. Hague, T.A.; Christoffersen, B.O. Evidence for peroxisomal retroconversion of adrenic acid $(22,4 n 6)$ and docosahexaenoic acid $(22,6 n 3)$ in isolated liver cells. Biochim. Biophys. Acta 1986, 875, 165-173.

25. Indu, M.; Ghafoorunissa, P. N-3 fatty acids in Indian diets-Comparison of the effects of precursor (alpha-linolenic acid) vs. product (long chain n-3 polyunsaturated fatty acids). Nutr. Res. 1992, 12, 569-582.

26. Ameur, A.; Enroth, S.; Johansson, A.; Zaboli, G.; Igl, W.; Johansson, A.C.; Rivas, M.A.; Daly, M.J.; Schmitz, G.; Hicks, A.A.; et al. Genetic Adaptation of Fatty-Acid Metabolism: A Human-Specific Haplotype Increasing the Biosynthesis of Long-Chain w-3 and w-6 Fatty Acids. Am. J. Hum. Genet. 2012, 90, 809-820. [PubMed]

27. Sergeant, S.; Hugenschmidt, C.E.; Rudock, M.E.; Ziegler, J.T.; Ivester, P.; Ainsworth, H.C.; Vaidya, D.; Case, L.D.; Langefeld, C.D.; Freedman, B.I.; et al. Differences in arachidonic acid levels and fatty acid desaturase (FADS) gene variants in African Americans and European Americans with diabetes or the metabolic syndrome. Br. J. Nutr. 2012, 107, 547-555. [PubMed]

28. Mathias, R.A.; Sergeant, S.; Ruczinski, I.; Torgerson, D.G.; Hugenschmidt, C.E.; Kubala, M.; Vaidya, D.; Suktitipat, B.; Ziegler, J.T.; Ivester, P.; et al. The impact of FADS genetic variants on $\omega 6$ polyunsaturated fatty acid metabolism in African Americans. BMC Genet. 2011, 12, 50.

29. Carlson, S.E.; Rhodes, P.G.; Ferguson, M.G. Docosahexaenoic acid status of preterm infants at birth and following feeding with human milk or formula. Am. J. Clin. Nutr. 1986, 44, 798-804. [PubMed] 
30. Singer, P.; Jaeger, W.; Voigt, S.; Theil, H. Defective desaturation and elongation of $n-6$ and $n-3$ fatty acids in hypertensive patients. Prostaglandins Leukot. Med. 1984, 15, 159-165. [CrossRef]

31. Honigmann, G.; Schimke, E.; Beitz, J.; Mest, H.J.; Schliack, V. Influence of a diet rich in linolenic acid on lipids, thrombocyte aggregation and prostaglandins in type I (insulin-dependent) diabetes. Diabetologia 1982, 23, 175.

32. Simopoulos, A.P. Essential fatty acids in health and chronic disease. Am. J. Clin. Nutr. 1999, 70 (Suppl.), 560S-569S. [PubMed]

33. Simopoulos, A.P. The importance of the $\omega-6 / \omega-3$ Balance in Health and Disease: Evolutionary Aspects of Diet. In Healthy Agriculture, Healthy Nutrition, Healthy People; Simopoulos, A.P., Ed.; Karger: Basel, Switzerland, 2011; Volume 102, pp. 10-21.

34. Eaton, S.B.; Konner, M. Paleolithic nutrition. A consideration of its nature and current implications. N. Engl. J. Med. 1985, 312, 283-289. [CrossRef] [PubMed]

35. Simopoulos, A.P. Overview of evolutionary aspects of $\omega 3$ fatty acids in the diet. In The Return of $\omega-3$ Fatty Acids into the Food Supply. I. Land-Based Animal Food Products and Their Health Effects; Simopoulos, A.P., Ed.; Karger: Basel, Switzerland, 1998; Volume 83, pp. 1-11.

36. Crawford, M.A. Fatty acid ratios in free-living and domestic animals. Lancet 1968, 1, 1329-1333. [CrossRef]

37. Wo, C.K.; Draper, H.H. Vitamin E status of Alaskan Eskimos. Am. J. Clin. Nutr. 1975, 28, 808-813.

38. Crawford, M.A.; Gale, M.M.; Woodford, M.H. Linoleic acid and linoleic acid elongation products in muscle tissue of Syncerus caffer and other ruminant species. Biochem. J. 1969, 115, 25-27. [CrossRef] [PubMed]

39. Raper, N.R.; Cronin, F.J.; Exler, J. w-3 fatty acid content of the US food supply. J. Am. College Nutr. 1992, 11, 304. [CrossRef]

40. Simopoulos, A.P.; Salem, N., Jr. Purslane: A terrestrial source of $\omega-3$ fatty acids. N. Engl. J. Med. 1986, 315, 833. [PubMed]

41. Van Vliet, T.; Katan, M.B. Lower ratio of $n-3$ to $n-6$ fatty acids in cultured than in wild fish. Am. J. Clin. Nutr. 1990, 51, 1-2.

42. Simopoulos, A.P.; Salem, N., Jr. Egg yolk as a source of long-chain polyunsaturated fatty acids in infant feeding. Am. J. Clin. Nutr. 1992, 55, 411-414. [PubMed]

43. Simopoulos, A.P.; Norman, H.A.; Gillapsy, J.E.; Duke, J.A. Common purslane: A source of $\omega-3$ fatty acids and antioxidants. J. Am. Coll. Nutr. 1992, 11, 374-382. [CrossRef] [PubMed]

44. Simopoulos, A.P. Nutrition and Fitness. JAMA 1989, 261, 2862-2863. [CrossRef] [PubMed]

45. Simopoulos, A.P.; Salem, N., Jr. N-3 Fatty acid in eggs from range-fed Greek chickens. N. Engl. J. Med. 1989, 321, 1412. [PubMed]

46. Simopoulos, A.P.; Norman, H.A.; Gillapsy, J.E. Purlsane in human nutrition and its potential for world agriculture. In Plants in Human Nutrition; Simopoulos, A.P., Ed.; Karger: Basel, Switzerland, 1995; Volume 77, pp. 47-74.

47. Simopoulos, A.P. Trans-fatty acids. In Handbook of Lipids in Human Nutrition; Spiller, G.A., Ed.; CRC Press: Boca Raton, FL, USA, 1995; pp. 91-99.

48. Dupont, J.; White, P.J.; Feldman, E.B. Saturated and hydrogenated fats in food in relation to health. J. Am. Coll. Nutr. 1991, 10, 577-592. [CrossRef]

49. Litin, L.; Sacks, F. Trans-fatty acid content of common foods. N. Engl. J. Med. 1993, 329, 1969-1970. [CrossRef] [PubMed]

50. Guil, J.L.; Torija, M.E.; Gimenez, J.J.; Rodríguez, I. Identification of fatty acids in edible wild plants by gas chromatography. J. Chromatogr. A 1996, 719, 229-235. [CrossRef]

51. Cordain, L.; Martin, C.; Florant, G.; Watkins, B.A. The fatty acid composition of muscle, brain, marrow and adipose tissue in elk: Evolutionary implications for human dietary lipid requirements. World Rev. Nutr. Diet. 1998, 83, 225-226.

52. Sinclair, A.J.; Slattery, W.J.; O'Dea, K. The analysis of polyunsaturated fatty acids in meat by capillary gas-liquid chromatography. J. Food Sci. Agri. 1982, 33, 771-776. [CrossRef]

53. Simopoulos, A.P. The role of fatty acids in gene expression: Health implications. Ann. Nutr. Metab. 1996, 40, 303-311. [CrossRef] [PubMed]

54. Elton, S. Environments, Adaptation, and Evolutionary Medicine: Should We Be Eating a Stone Age Diet? In Medicine and Evolution: Current Applications, Future Prospects; Elton, S., O'Higgins, P., Eds.; CRC Press: Boca Raton, FL, USA, 2008; pp. 9-34. 
55. Eaton, S.B.; Konner, M.; Shostak, M. Stone agers in the fast lane: Chronic degenerative diseases in evolutionary perspective. Am. J. Med. 1988, 84, 739-749. [CrossRef]

56. Kuipers, R.S.; Luxwolda, M.F.; Dijck-Brouwer, D.A.; Eaton, S.B.; Crawford, M.A.; Cordain, L.; Muskiet, F.A. Estimated macronutrient and fatty acid intakes from an East African Paleolithic diet. Br. J. Nutr. 2010, 104, 1666-1687. [CrossRef] [PubMed]

57. Guil-Guerrero, J.L.; Tikhonov, A.; Rodríguez-García, I.; Protopopov, A.; Grigoriev, S.; Ramos-Bueno, R.P. The fat from frozen mammals reveals sources of essential fatty acids suitable for Palaeolithic and Neolithic humans. PLOS ONE 2014, 9, e84480.

58. Eaton, S.B.; Eaton, S.B., III; Sinclair, A.J.; Cordain, L.; Mann, N.J. Dietary intake of long-chain polyunsaturated fatty acids during the Paleolithic. In The Return of w-3 Fatty Acids into the Food Supply. I. Land-Based Animal Food Products and Their Health Effects; Simopoulos, A.P., Ed.; Karger: Basel, Switzerland, 1998; Volume 83, pp. 12-23.

59. Simopoulos, A.P. Importance of the ratio of $\omega-6 / \omega-3$ essential fatty acids: Evolutionary aspects. In Omega-6/Omega-3 Essential Fatty Acid Ratio: The Scientific Evidence; Simopoulos, A.P., Cleland, L.G., Eds.; Karger: Basel, Switzerland, 2003; Volume 92, pp. 1-22.

60. Amri, E.Z.; Ailhaud, G.; Grimaldi, P.A. Fatty acids as signal transducing molecules: Involvement in the differentiation of preadipose to adipose cells. J. Lipid Res. 1994, 35, 930-937. [PubMed]

61. Jump, D.B.; Clarke, S.D.; Thelen, A.; Liimatta, M. Coordinate regulation of glycolytic and lipogenic gene expression by polyunsaturated fatty acids. J. Lipid Res. 1994, 35, 1076-1084. [PubMed]

62. Clarke, S.D.; Jump, D. Polyunsaturated fatty acids regulate lipogenic and peroxisomal gene expression by independent mechanisms. Prostaglandins Leukot. Essent. Fatty Acids 1997, 57, 65-69. [CrossRef]

63. Schwinkendorf, D.R.; Tsatsos, N.G.; Gosnell, B.A.; Mashek, D.G. Effects of central administration of distinct fatty acids on hypothalamic neuropeptide expression and energy metabolism. Int. J. Obes. 2011, 35, 336-344. [CrossRef] [PubMed]

64. James, M.J.; Gibson, R.A.; Cleland, L.G. Dietary polyunsaturated fatty acids and inflammatory mediator production. Am. J. Clin. Nutr. 2000, 71, 343S-348S. [PubMed]

65. Gaillard, D.; Negrel, R.; Lagarde, M.; Ailhaud, G. Requirement and role of arachidonic acid in the differentiation of preadipose cells. Biochem. J. 1989, 257, 389-397. [CrossRef] [PubMed]

66. Corey, E.J.; Shih, C.; Cashman, J.R. Docosahexaenoic acid is a strong inhibitor of prostaglandin but not leukotriene biosynthesis. Proc. Natl. Acad. Sci. USA 1983, 80, 3581-3584. [CrossRef] [PubMed]

67. Massaro, M.; Habib, A.; Lubrano, L.; Del Turco, S.; Lazzerini, G.; Bourcier, T.; Weksler, B.B.; De Caterina, R. The omega-3 fatty acid docosahexaenoate attenuates endothelial cyclooxygenase-2 induction through both NADP(H) oxidase and PKC epsilon inhibition. Proc. Natl. Acad. Sci. USA 2006, 103, 15184-15189. [CrossRef] [PubMed]

68. Ringbom, T.; Huss, U.; Stenholm, A.; Flock, S.; Skattebol, L.; Perera, P.; Bohlin, L. Cox-2 inhibitory effects of naturally occurring and modified fatty acids. J. Nat. Prod. 2001, 64, 745-749. [CrossRef] [PubMed]

69. Mirnikjoo, B.; Brown, S.E.; Kim, H.F.; Marangell, L.B.; Sweatt, J.D.; Weeber, E.J. Protein kinase inhibition by omega-3 fatty acids. J. Biol. Chem. 2001, 276, 10888-10896. [CrossRef] [PubMed]

70. Hennig, B.; Watkins, B.A. Linoleic acid and linolenic acid: Effect on permeability properties of cultured endothelial cell monolayers. Am. J. Clin. Nutr. 1989, 49, 301-305. [PubMed]

71. Ukropec, J.; Reseland, J.E.; Gasperikova, D.; Demcakova, E.; Madsen, L.; Berge, R.K.; Rustan, A.C.; Klimes, I.; Drevon, C.A.; Sebokova, E. The hypotriglyceridemic effect of dietary $n-3$ FA is associated with increased beta-oxidation and reduced leptin expression. Lipids 2003, 38, 1023-1029. [CrossRef] [PubMed]

72. Lepperdinger, G. Inflammation and mesenchymal stem cell aging. Curr. Opin. Immunol. 2011, $23,518-524$. [CrossRef] [PubMed]

73. Massiera, F.; Barbry, P.; Guesnet, P.; Joly, A.; Luquet, S.; Moreilhon-Brest, C.; Mohsen-Kanson, T.; Amri, E.Z.; Ailhaud, G. A Western-like fat diet is sufficient to induce a gradual enhancement in fat mass over generations. J. Lipid Res. 2010, 51, 2352-2561. [CrossRef] [PubMed]

74. Pisani, D.F.; Amri, E.Z.; Ailhaud, G. Disequilibrium of polyunsaturated fatty acids status and its dual effect in modulating adipose tissue development and functions. OCL 2015, 22, D405. [CrossRef]

75. Baillie, R.A.; Takada, R.; Nakamura, M.; Clarke, S.D. Coordinate induction of peroxisomal acyl-CoA oxidase and UCP-3 by dietary fish oil: A mechanism for decreased body fat deposition. Prostaglandins Leukot. Essent. Fatty Acids 1999, 60, 351-356. [CrossRef] 
76. Phillips, C.M.; Goumidi, L.; Bertrais, S.; Field, M.R.; Ordovas, J.M.; Cupples, L.A.; Defoort, C.; Lovegrove, J.A.; Drevon, C.A.; Blaak, E.E.; et al. Leptin receptor polymorphisms interact with polyunsaturated fatty acids to augment risk of insulin resistance and metabolic syndrome in adults. J. Nutr. 2010, 140, 238-244. [PubMed]

77. Cheng, L.; Yu, Y.; Zhang, Q.; Szabo, A.; Wang, H.; Huang, X.F. Arachidonic acid impairs hypothalamic leptin signaling and hepatic energy homeostasis in mice. Mol. Cell. Endocrinol. 2015, 5, 412, 12-18. [CrossRef]

78. Perez-Matute, P.; Perez-Echarri, N.; Martinez, J.A.; Marti, A.; Moreno-Aliaga, M.J. Eicosapentaenoic acid actions on adiposity and insulin resistance in control and high-fat-fed rats: Role of apoptosis, adiponectin and tumour necrosis factor-alpha. Br. J. Nutr. 2007, 97, 389-398. [CrossRef] [PubMed]

79. Hassanali, Z.; Ametaj, B.N.; Field, C.J.; Proctor, S.D.; Vine, D.F. Dietary supplementation of $n-3$ PUFA reduces weight gain and improves postprandial lipaemia and the associated inflammatory response in the obese JCR: LA-cp rat. Diabetes Obes. Metab. 2010, 12, 139-147. [CrossRef] [PubMed]

80. Alvheim, A.R.; Torstensen, B.E.; Lin, Y.H.; Lillefosse, H.H.; Lock, E.J.; Madsen, L.; Frøyland, L.; Hibbeln, J.R.; Malde, M.K. Dietary linoleic acid elevates the endocannabinoids 2-AG and anandamide and promotes weight gain in mice fed a low fat diet. Lipids 2014, 49, 59-69. [CrossRef] [PubMed]

81. Banni, S.; Di Marzo, V. Effect of dietary fat on endocannabinoids and related mediators: consequences on energy homeostasis, inflammation and mood. Mol. Nutr. Food Res. 2010, 54, 82-92. [CrossRef] [PubMed]

82. Matias, I.; Di Marzo, V. Endocannabinoids and the control of energy balance. Trends Endocrinol. Metab. 2007, 18, 27-37. [CrossRef] [PubMed]

83. Buckley, J.D.; Howe, P.R. Anti-obesity effects of long-chain omega-3 polyunsaturated fatty acids. Obes. Rev. 2009, 10, 648-659. [CrossRef] [PubMed]

84. Hainault, I.; Carolotti, M.; Hajduch, E.; Guichard, C.; Lavau, M. Fish oil in a high lard diet prevents obesity, hyperlipemia, and adipocyte insulin resistance in rats. Ann. N. Y. Acad. Sci. 1993, 683, 98-101. [CrossRef] [PubMed]

85. Belzung, F.; Raclot, T.; Groscolas, R. Fish oil $n-3$ fatty acids selectively limit the hypertrophy of abdominal fat depots in growing rats fed high-fat diets. Am. J. Physiol. 1993, 264, R1111-R1118. [PubMed]

86. Parrish, C.C.; Pathy, D.A.; Angel, A. Dietary fish oils limit adipose tissue hypertrophy in rats. Metabolism 1990, 39, 217-219. [CrossRef]

87. Ruzickova, J.; Rossmeisl, M.; Prazak, T.; Flachs, P.; Sponarova, J.; Veck, M.; Tvrzicka, E.; Bryhn, M.; Kopecky, J. Omega-3 PUFA of marine origin limit diet-induced obesity in mice by reducing cellularity of adipose tissue. Lipids 2004, 39, 1177-1185. [CrossRef] [PubMed]

88. Nuernberg, K.; Breier, B.H.; Jayasinghe, S.N.; Bergmann, H.; Thompson, N.; Nuernberg, G.; Dannenberger, D.; Schneider, F.; Renne, U.; Langhammer, M.; et al. Metabolic responses to high-fat diets rich in $n-3$ or $n-6$ long-chain polyunsaturated fatty acids in mice selected for either high body weight or leanness explain different health outcomes. Nutr. Metab. 2011, 8, 56. [PubMed]

89. Kang, J.X.; Wang, J.; Wu, L.; Kang, Z.B. Transgenic mice: Fat-1 mice convert $n-6$ to $n-3$ fatty acids. Nature 2004, 427, 504. [CrossRef] [PubMed]

90. Jump, D.B.; Clarke, S.D. Regulation of gene expression by dietary fat. Annu. Rev. Nutr. 1999, 19, 63-90. [CrossRef] [PubMed]

91. Jump, D.B. Dietary polyunsaturated fatty acids and regulation of gene transcription. Curr. Opin. Lipidol. 2002, 13, 155-164. [CrossRef] [PubMed]

92. Suzukawa, M.; Abbey, M.; Howe, P.R.; Nestel, P.J. Effects of fish oil fatty acids on low-density lipoprotein size, oxidizability, and uptake by macrophages. J. Lipid Res. 1995, 36, 473-484. [PubMed]

93. Li, J.; Li, F.R.; Wei, D.; Jia, W.; Kang, J.X.; Stefanovic-Racic, M.; Dai, Y.; Zhao, A.Z. Endogenous $\omega-3$ Polyunsaturated Fatty Acid Production Confers Resistance to Obesity, Dyslipidemia, and Diabetes in Mice. Mol. Endocrinol. 2014, 28, 1316-1328. [CrossRef] [PubMed]

94. Kabir, M.; Skurnik, G.; Naour, N.; Pechtner, V.; Meugnier, E.; Rome, S.; Quignard-Boulangé, A.; Vidal, H.; Slama, G.; Clément, K.; et al. Treatment for 2 mo with $n 3$ polyunsaturated fatty acids reduces adiposity and some atherogenic factors but does not improve insulin sensitivity in women with type 2 diabetes: A randomized controlled study. Am. J. Clin. Nutr. 2007, 86, 1670-1679.

95. Thorsdottir, I.; Tomasson, H.; Gunnarsdottir, I.; Gisladottir, E.; Kiely, M.; Parra, M.D.; Bandarra, N.M.; Schaafsma, G.; Martinéz, J.A. Randomized trial of weight-loss-diets for young adults varying in fish and fish oil content. Int. J. Obes. 2007, 31, 1560-1566. [CrossRef] [PubMed] 
96. Parra, D.; Ramel, A.; Bandarra, N.; Kiely, M.; Martinez, J.A.; Thorsdottir, I. A diet rich in long chain omega-3 fatty acids modulates satiety in overweight and obese volunteers during weight loss. Appetite 2008, 51, 676-680. [CrossRef] [PubMed]

97. Krebs, J.D.; Browning, L.M.; McLean, N.K.; Rothwell, J.L.; Mishra, G.D.; Moore, C.S.; Jebb, S.A. Additive benefits of long-chain $n-3$ polyunsaturated fatty acids and weight-loss in the management of cardiovascular disease risk in overweight hyperinsulinaemic women. Int. J. Obes. 2006, 30, 1535-1544. [CrossRef] [PubMed]

98. Kunesova, M.; Braunerová, R.; Hlavatý, P.; Tvrzická, E.; Stanková, B.; Skrha, J.; Hilgertová, J.; Hill, M.; Kopecký, J.; Wagenknecht, M.; et al. The influence of $n-3$ polyunsaturated fatty acids and very low calorie diet during a short-term weight reducing regimen on weight loss and serum fatty acid composition in severely obese women. Physiol. Res. 2006, 55, 63-72. [PubMed]

99. Simopoulos, A.P. Genetic variants in the metabolism of omega- 6 and omega- 3 fatty acids: their role in the determination of nutritional requirements and chronic disease risk. Exp. Biol. Med. 2010, 235, 785-795. [CrossRef] [PubMed]

100. Wang, L.; Manson, J.E.; Rautiainen, S.; Gaziano, J.M.; Buring, J.E.; Tsai, M.Y.; Sesso, H.D. A prospective study of erythrocyte polyunsaturated fatty acid, weight gain, and risk of becoming overweight or obese in middle-aged and older women. Eur. J. Nutr. 2015. [CrossRef] [PubMed]

101. Claussnitzer, M.; Dankel, S.N.; Kim, K.H.; Quon, G.; Meuleman, W.; Haugen, C.; Glunk, V.; Sousa, I.S.; Beaudry, J.L.; Puviindran, V.; et al. FTO Obesity Variant Circuitry and Adipocyte Browning in Humans. N. Engl. J. Med. 2015, 373, 895-907. [PubMed]

102. Savva, S.C.; Chadjigeorgiou, C.; Hatzis, C.; Kyriakakis, M.; Tsimbinos, G.; Tornaritis, M.; Kafatos, A. Association of adipose tissue arachidonic acid content with BMI and overweight status in children from Cyprus and Crete. Br. J. Nutr. 2004, 91, 643-649. [CrossRef] [PubMed]

103. Jensen, C.L.; Prager, T.C.; Fraley, J.K.; Chen, H.; Anderson, R.E.; Heird, W.C. Effect of dietary linoleic/alpha-linolenic acid ratio on growth and visual function of term infants. J. Pediatr. 1997, 131, 200-209. [CrossRef]

104. Ahima, R.S.; Antwi, D.A. Brain regulation of appetite and satiety. Endocrinol. Metab. Clin. N. Am. 2008, 37, 811-823. [CrossRef] [PubMed]

105. Artmann, A.; Petersen, G.; Hellgren, L.; Boberg, J.; Skonberg, C.; Nellemann, C.; Hansen, S.H.; Hansen, H.S. Influence of dietary fatty acids on endocannabinoid and $\mathrm{N}$-acylethanolamine levels in rat brain, liver and small intestine. Biochim. Biophys. Acta 2008, 1781, 200-212. [CrossRef] [PubMed]

106. Yoshida, R.; Ohkuri, T.; Jyotaki, M.; Yasuo, T.; Horio, N.; Yasumatsu, K.; Sanematsu, K.; Shigemura, N.; Yamamoto, T.; Margolskee, R.F.; et al. Endocannabinoids selectively enhance sweet taste. Proc. Natl. Acad. Sci. USA 2010, 107, 935-939. [CrossRef] [PubMed]

107. Van Gaal, L.; Pi-Sunyer, X.; Despres, J.P.; McCarthy, C.; Scheen, A. Efficacy and safety of rimonabant for improvement of multiple cardiometabolic risk factors in overweight/obese patients: Pooled 1-year data from the Rimonabant in Obesity (RIO) program. Diabetes Care 2008, 31, S229-S240. [CrossRef] [PubMed]

108. Christensen, R.; Kristensen, P.K.; Bartels, E.M.; Bliddal, H.; Astrup, A. Efficacy and safety of the weight-loss drug rimonabant: a meta-analysis of randomised trials. Lancet 2007, 370, 1706-1713. [CrossRef]

(C) 2016 by the author; licensee MDPI, Basel, Switzerland. This article is an open access article distributed under the terms and conditions of the Creative Commons by Attribution (CC-BY) license (http://creativecommons.org/licenses/by/4.0/). 